\title{
STEAM Learning in Early Childhood Education: A Literature Review
}

\author{
Wahyuningsih, $\mathbf{S}^{1}$, Nurjanah, N.E ${ }^{2}$, Rasmani, U.E.E ${ }^{3}$, Hafidah, $\mathbf{R}^{4}$, \\ Pudyaningtyas, A.R ${ }^{5}$, Syamsuddin, M.M ${ }^{6}$ \\ 1,2,3,4,5,6 Early Childhood Education, Universitas Sebelas Maret, Indonesia \\ Corresponding email: siti_w@staff.uns.ac.id
}

\begin{abstract}
This literature review covers articles and books about STEAM (Science, Technology, Engineering, Arts, and Mathematics) in early childhood education. STEAM learning is considered to be an appropriate approach to answering the challenges of the $21^{\text {st }}$ century as it integrates the hard and soft skills needed by children. It is exciting to note that in most articles, STEAM is a popular pedagogical method to improve creativity, problem-solving skills, scientific inquiry and critical thinking, and to provide other cognitive benefits. It is taught in integrated learning in early childhood education and is conducted through children's daily observation. The literature also discusses that the impact of STEAM learning makes children more active and able to take initiatives in their own knowledge. Teachers who are influenced by the integrated professional development of STEAM positively influence children through their professional learning. Another finding from this review is that experience of STEAM can increase children's self-confidence. In addition, STEAM learning is considered to be able to integrate the skills needed by children. STEAM encourages children to build knowledge about the world around them by observing, investigating and asking questions. This review aims to consider advanced learning in early childhood education through STEAM.
\end{abstract}

Keywords: STEAM; learning; early childhood education

DOI: https://dx.doi.org/10.20961/ijpte.v4i1.39855

Except where otherwise noted, content on this site is licensed under a Creative Commons Attribution 4.0 International License. 


\section{INTRODUCTION}

Education in the 21 st century, which has entered disruption and the 4.0 digital era, must continue to innovate (Yakman \& Lee, 2012). The rapid development of science and information also supports the rapid development of technology. The changes that are occurring in all fields of life also affect human lives. Many aspects of human power are starting to be replaced by mechanical power and artificial intelligence is also developing rapidly. Therefore, people who live in this era must also adjust to these changes, so that they can continue to maintain their existence.

Early childhood education, as one of the basic education institutions, must also be prepared to answer the challenges of this era (Draper \& Wood, 2017); it needs to make changes in both the curriculum and learning. Children who study in such education programmes must develop various kinds of skills (hard and soft) to be able to adapt to the changes taking place around them. The skills that need to be taught include critical thinking, creative thinking (creativity), cooperation, communication, physical knowledge, logical mathematics, and social. These skills must be integrated into the learning process.

These skills are important for basic learning in early childhood to ensure students have learning and innovation skills, technology and skills information media, and can work and survive using their skills for life. Children are born curious. Actions play a fundamental role in the concept of learning; in this sense, children are scientists. Scientific programmes must, thus, be designed in such a way that children are provided with a well-thought-out structure, on which they can build their exploration and be involved in situations that lead to new questions. The skills that emerge can also undoubtedly be used in other content domains, such as mathematics, technology and language. For example, when children learn to compare, sort, count, estimate, classify, measure, graph and even share their explanations with others in their science activities, a transfer of these skills to mathematics, language and technology will be expected (Dejonckheere, De Wit, Van de Keere \& Vervaet, 2016).

This STEAM learning began with STEM. The STEM movement emerged in the early 1990s. Although the National Science Foundation began using the acronym 'SMET', it was decided that it should be changed to STEM (science, technology, engineering, and mathematics) for phonetic reasons (Martín-Páez, Aguilera, Perales-Palacios \& Vílchez-González, 2019). STEM education benefits schools and local communities, and promises a positive impact on students, teachers, school leaders, community members and the workforce in the future (Avendano, Renteria, Kwon \& Hamdan, 2019). STEM can improve students' reasoning and critical thinking skills, creativity, and innovation through an integrated and connected STEM curriculum and pedagogical practices, providing fairness for students from various backgrounds (Purakom \& Soykeree, n.d.). Along with the growing popularity of STEAM in American K-12 schools, scholars have proposed various pedagogical models and approaches to develop and integrate art into STEM classes. STEM education is now starting to combine art, and the 
similarities between art and education promote creativity. Empirical research has shown that education in the arts can increase student creativity, critical thinking, innovation, collaboration, and interpersonal communication skills. The recognised results and benefits of this art education are the inspiration for the STEAM concept, which was introduced in Indonesia, United States in 2007 (Perignat \& Katz-Buonincontro, 2019).

The term 'STEAM education' refers to teaching and learning in the fields of science, technology, engineering, art, and mathematics (Gonzales \& Kuenzi, 2012). It usually includes educational activities at all grade levels, from preschool to post-doctoral. STEAM learning is considered as learning that can integrate skills (hard and soft) that are needed by children. The term STEAM originated from STEM, which encourages children to build knowledge about the world around them through observiion, investigation and asking questions (Ata Aktürk, Demircan, Şenyurt \& Çetin, 2017). STEM is considered to provide valuable and meaningful learning for children. Teachers and educators believe that with such learning, students will be more active and more able to think critically in building their knowledge (Tippett \& Milford, 2017). The addition of the 'arts' (leading to the acronym STEAM) will give children the opportunity to describe the STEM concept in creative and imaginative ways (Radziwill, Benton, \& Moellers, 2015; Siantajani, 2018).

STEAM is utilised to focus on understanding the integrated nature of scientific, technological, engineering, artistic and mathematical disciplines, and their importance in the long-term academic success of children, economic well-being (Herro, 2016) and community development (Han, Rosli, 2016). STEM education includes grades from pre-school to post-doctoral levels and from formal learning settings (e.g. classrooms) to informal education (e.g. afterschool programmes (Gonzales \& Kuenzi, 2012). As an illustration, STEM education has been recognised in the US as an important educational reform and is described as an instructional approach to prepare children for the global economy this century (Yakman, 2018). It cannot be denied that STEM learning in early childhood is very important. It mainly concerns initial exposure to reasoning, predicting, hypothesising, problem solving and critical thinking, rather than simply memorising and practising.

Research and literature on STEAM learning in early childhood is very limited, so a literature review was conducted. This is reinforced by the opinion of Brophy, Klein, Portsmore and Rogers (2008) and Petroski (2003), who believe that science, technology, engineering, arts, and mathematics (STEAM) in early childhood education is an area to which little attention is paid in the literature; this is unfortunate because young children are natural scientists and engineers. The literature review aims to analyse work on learning in early childhood that applies STEAM, selected through a literature review of various research articles, with the goal of providing an overview of STEAM learning in 21st-century early childhood education. 


\section{METHODS}

The research employed the literature review method. In a conceptual review, the researcher aims to provide an overview of the literature in a particular field, including the main ideas, models and debates (Petticrew \& Roberts, 2006). Galvan and Galvan (2017) advise that such a review will be made easier if the major theories that apply to the topic of interest are identified. This paper aims to conduct a literature review that examines studies related to STEAM learning in early childhood education. The literature was chosen from online and printed sources, including books and journal articles. Searches were conducted through EBSCOHOST, SCIENCE DIRECT and Scopus indexed open access journals, using key words such as STEAM, learning, and early childhood education. The sources identified were mostly published between 2007 and 2019; this timeframe was not specifically chosen by the researchers.

Table 1. Limitations of the review

\begin{tabular}{ll}
\hline Year of publication & $2007-2019$ \\
\hline Databases & $\begin{array}{l}\text { EBSCOHOST, SCIENCE DIRECT, Scopus } \\
\text { indexed open access journals }\end{array}$ \\
\hline Types of document & Articles, books \\
\hline Subject & Early childhood \\
\hline Keywords & STEAM, learning, early childhood education \\
\hline
\end{tabular}

\section{RESULT AND DISCUSSION}

The studies that qualified for the review process were examined in detail and summarised in categories that are determined and appear. The findings include parts that refer to that category. The sources were evaluated for eligibility and relevance based on predetermined categories, such as STEAM, learning, and early childhood education. Related references in the sources were examined are also analysed, and relevant ones were included in the collection. In accordance with the specified categories, 40 studies were selected for the review process and summarised based on the categories.

Table 2. Results of Review on STEAM ( $\mathrm{N}=40$ Articles)

\begin{tabular}{|c|c|c|}
\hline Category & Focus area & Example article \\
\hline \multirow{4}{*}{$\begin{array}{l}\text { Use of STEAM in early } \\
\text { childhood education }\end{array}$} & $\begin{array}{l}\text { Science application in early } \\
\text { childhood STEAM learning }\end{array}$ & $\begin{array}{l}\text { Land, 2013; Aldemir \& } \\
\text { Kermani, 2017; Britto et al., } \\
\text { 2017; Krogh, S.L \& Slent, } \\
\text { 2008; Madden et al., } 2013\end{array}$ \\
\hline & $\begin{array}{l}\text { Technology application in } \\
\text { early childhood STEAM } \\
\text { learning }\end{array}$ & $\begin{array}{l}\text { Palou et al., 2015; } \\
\text { Henriksen, 2017; Jackman } \\
\text { 2009; Alam \& Perry, } 2002\end{array}$ \\
\hline & $\begin{array}{l}\text { Engineering application in } \\
\text { early childhood STEAM } \\
\text { learning }\end{array}$ & $\begin{array}{l}\text { McClure et al., 2017; } \\
\text { Taylor, } 2016\end{array}$ \\
\hline & $\begin{array}{l}\text { Arts application in early } \\
\text { childhood STEAM learning }\end{array}$ & $\begin{array}{l}\text { Maeda, 2013; Doyle, 2017; } \\
\text { Radziwill et al., 2015; }\end{array}$ \\
\hline
\end{tabular}




\begin{tabular}{|c|c|c|}
\hline Category & Focus area & Example article \\
\hline \multirow{3}{*}{$\begin{array}{l}\text { Use of STEAM in early } \\
\text { childhood education }\end{array}$} & & $\begin{array}{l}\text { Dejonckheere et al., 2016; } \\
\text { Purakom \& Soykeree, n.d }\end{array}$ \\
\hline & $\begin{array}{l}\text { Mathematics application in } \\
\text { early childhood STEAM } \\
\text { learning }\end{array}$ & $\begin{array}{l}\text { Krogh, S.L \& Slentz, 2008; } \\
\text { Perignat \& Katz- } \\
\text { Buonincontro, } 2019\end{array}$ \\
\hline & $\begin{array}{l}\text { Loose parts are an important } \\
\text { element of STEAM-based } \\
\text { learning }\end{array}$ & $\begin{array}{l}\text { Casey et al., 2016; Herro, } \\
\text { 2016; Han \& Rosli, 2016; } \\
\text { Gonzales \& Kuenzi, 2012; } \\
\text { Yakman, } 2018\end{array}$ \\
\hline \multirow{6}{*}{ Impact of STEAM learning } & $\begin{array}{l}\text { Improve vocabulary, } \\
\text { collaboration, and transmit } \\
\text { learning into future } \\
\text { experiences }\end{array}$ & $\begin{array}{l}\text { Bagiati and Evangelou, } \\
\text { 2015; Buchmann \& } \\
\text { Schwille, 1983; McClure et } \\
\text { al. 2017; Ata Aktürk et al., } \\
\text { 2017; Davis, } 2010\end{array}$ \\
\hline & $\begin{array}{l}\text { Increased language } \\
\text { development, } \\
\text { emotional development, } \\
\text { motor development, and } \\
\text { self-confidence }\end{array}$ & $\begin{array}{l}\text { Andersson and Gullberg, } \\
\text { 2014; Campbell, } \\
\text { Speldewinde, Howitt \& } \\
\text { MacDonald, } 2018\end{array}$ \\
\hline & $\begin{array}{l}\text { Influences the acquisition of } \\
\text { knowledge and skills in the } \\
\text { early childhood education }\end{array}$ & $\begin{array}{l}\text { Kermani, H., \& Aldemir, } \\
2018\end{array}$ \\
\hline & $\begin{array}{l}\text { Offers many opportunities } \\
\text { for students to be active and } \\
\text { involved, and to take } \\
\text { initiatives in their own } \\
\text { learning }\end{array}$ & $\begin{array}{l}\text { Linder, Emerson, Heffron, } \\
\text { Shevlin \& Vest, } 2016\end{array}$ \\
\hline & $\begin{array}{l}\text { Improve creativity and } \\
\text { imaginative }\end{array}$ & $\begin{array}{l}\text { Siantajani, 2018; Radziwill } \\
\text { et al., } 2015\end{array}$ \\
\hline & $\begin{array}{l}\text { Educational reforms to } \\
\text { prepare in the long-term } \\
\text { academic success of } \\
\text { children and economic well- } \\
\text { being }\end{array}$ & $\begin{array}{l}\text { Herro, 2016; } \\
\text { Han \& Rosli, } 2016 \\
\text { Gonzales \& Kuenzi, 2012; } \\
\text { Brophy, Klein, Portsmore } \\
\text { and Rogers 2008; Petroski, } \\
\text { 2003; Avendano, Renteria, } \\
\text { Kwon \& Hamdan, 2019; } \\
\text { Ata Aktürk, Demircan, } \\
\text { Senyurt \& Cetin, } 2017\end{array}$ \\
\hline
\end{tabular}

\section{Use of STEAM in early childhood education}

Learning that welcomes children to the 21 st century is based on STEAM learning. In supporting the development of the STEAM curriculum, teachers must be involved in designing and planning STEAM learning (Land, 2013); their role is very important in supporting the success of such learning in early childhood. Children who attend preschool can achieve a higher level of STEAM understanding when they are specifically supported through planned, stimulating and developmentally appropriate activities (Aldemir \& Kermani, 2017).

This section reviews integrated STEAM learning in early childhood education. Science is often the subject that is left to the end if there is little time left, or is even ignored 
altogether by the teacher (Britto et al., 2017). However, for young children, it is often the subject that makes them most curious, excited and thirsty for learning (Krogh \& Slentz, 2008). By definition, science refers to knowledge acquired systematically through observation, study and experimentation. When applied to the natural world, it includes physics, chemistry and biology, as well as their derivatives and branches of study, such as astronomy, geology, oceanography, ecology, botany and zoology. Because the contents of these sciences are physical, approachable, and intertwined with children's lives, science not only appeals to them, but is also an appropriate part of their curriculum (Madden et al., 2013). The activities that teachers should conduct in teaching early childhood science include:

1) Planning scientific experiences in relation to the physical, social and moral, emotional, and cognitive development of children;

2) Developing a science curriculum that reflects the needs of each child; and

3) Beginning to plan a science study unit that integrates other fields of study.

Technology is another term for a tool. Adults think that technology is in the form of electronic goods or digital equipment, such as cameras, computers or sophisticated machines in factories (Palou et al., 2015). However, crayons, pencils, rulers and scissors are also tools. Any equipment used by children when playing is technology, from simple to modern forms, including simple machines that children come across in their daily lives (Henriksen, 2017). It should be ensured that the technology is appropriate for the age of the children, can be used according to their wishes and provides opportunities to solve problems.

According to Jackman (2009), technology in the 4.0 revolution era cannot be separated from its rapid development. This is because technology will not disappear, and we are in the middle of a major sociocultural quantum shift. Technology is revolutionising the world in which our children will live, so our job is to balance the development of appropriate skills in technology with the core principles and experience needed to raise healthy children (Alam \& Perry, 2002). Therefore, it is important to introduce technology from an early age.

Engineering and technology used to be less common as explicit subjects in the early years of education. Examples of engineering and technology in early childhood can be in the form of building fortresses and block games, and in explaining how to use simple tools such as scoops and scissors (McClure et al., 2017). The Ramps and Pathways study, a curriculum that encourages children to build ramps such as roller-coasters using simple wooden trims, balls, and other rolling objects, has shown that children can gain an understanding of the relationship between sloping angles and motion objects, as well as of the need to test, analyse, and process their designs. Engineering can be interpreted as the engineering of technology. Engineering starts with identifying a problem, followed by an attempt to solve that problem. For example, children experience a process when they try to discover how to make a strong foundation so that their building blocks can be taller (Taylor, 2016).

Expressive art includes drawing, painting, sculpture, architecture, music, literature, drama and dance. Art adds wealth to daily life and elevates our thoughts and feelings beyond ordinary events (Maeda, 2013). In the world of early childhood, expressive art involves all these subjects and more. The arts stimulate cognitive, social, emotional and physical development in early childhood (Doyle, 2017). Young children participate in music by singing, listening, moving, composing and playing, and even making their own instruments. Children's visual arts include drawing, painting of all kinds, various types of 
sculpture, and working with clay or similar materials. Children's abilities in arts-related experiences are influenced by their level of development, and vice versa, meaning the arts curriculum contributes to all areas of children's development (Radziwill et al., 2015).

The field of mathematics includes a variety of subfields, skills and systems, many of which are suitable for learning in a variety of forms by young children. Among the more commonly taught topics are classification, seriation, calculation, measurement, geometry, charts and arithmetic (Krogh \& Slentz, 2008). Activities conducted by teachers in the field of early childhood mathematics include:

1) Planning mathematical activities to stimulate children's physical, social and cognitive development;

2) Planning maths activities by considering the needs of each child; and

3) Incorporating mathematical activities into all curriculum areas.

The ability to think at a higher level of mathematics arises when children are helped to understand that comparisons are relative, depending on what is being compared at the time (Perignat \& Katz-Buonincontro, 2019). The concept of mathematics is better understood when mathematics becomes part of daily activities. Other curriculum areas can enter the field of mathematics easily and successfully.

STEAM-based learning takes place in an integrated way in early childhood education. Loose parts are an important element of STEAM-based learning. These are open items, which are easily found in our daily environment (Casey et al., 2016). Nature is full of such items, such as twigs, pine seeds, shells, stones, leaves, flowers and other natural objects. Parents and teachers can collect these from anywhere, at no cost.

Loose parts not only support children's development, but also help them to connect with their environment. Toys are designed with a specific purpose and are usually used by children in only one or two ways. Children who bring a basket of cars will usually use these to play with, but when they use objects from nature, they can use them in any way, according to their own ideas. This will develop children's imagination, creativity, language and knowledge.

STEAM is used to focus on understanding the integrated nature of scientific, technological, engineering, artistic, and mathematical disciplines and their importance in the long-term academic success of children, economic well-being (Herro, 2016) and community development (Han \& Rosli, 2016). STEM education includes grades from preschool to post-doctoral levels and formal learning settings (e.g. classrooms) and informal education (e.g. afterschool programmes) (Gonzales \& Kuenzi, 2012). As an illustration, STEM education has been recognised in the US as an important educational reform and is described as an instructional approach to prepare children for the global economy this century (Yakman, 2018).

\section{Impact of STEAM learning}

Bagiati and Evangelou (2015) focus on developing the STEM curriculum in early education with an emphasis on engineering. Their study presents the teacher's experience when undertaking the task of becoming accustomed to new content and using the curriculum in university-based lab school classes in the US. More specifically, the article explains and analyses the collaboration between teachers and curriculum developers. Technical education in previous years was an academic discipline that grew out of the need to understand and improve the way engineers were formally educated. Beliefs about 
early experience as a determinant of later experience have long been the basis of educational planning (Buchmann \& Schwille, 1983). Therefore, identifying age and the exact way in which early childhood education is part of technical education is very important in the current climate.

According to McClure et al. (2017), children can and must be involved in STEM learning, even in the early years of life. We now know that very young children are far more capable of learning about STEM concepts and practices than predicted. In fact, more and more research shows a correlation between initial experience with STEM subjects and subsequent success in these subjects or in schools in general. Furthermore, a study by (Ata Aktürk et al., 2017) shows that during the early years of childhood, STEM activities allow children to find material using their senses. In this way, they can understand significant scientific and mathematical associations, such as 'more or less' and 'sooner or later' concepts from an early age. In addition, STEM serves children by increasing their vocabulary, encouraging collaboration, and transmitting their learning into their future experiences (Davis, 2010).

According to Andersson and Gullberg (2014), children make contact with science and begin learning scientific language to increase their scientific gain and to direct them to think like scientists. This interest gained by children who are willing to investigate what is happening around them can be increased during the rest of their lives. Therefore, the objectives and indicators in curricula related to other fields of development, such as language, socio-emotional, and motor development can be enriched by considering STEM practices and activities can be planned to achieve these goals and indicators. Moreover, children's STEM experiences can increase their confidence in their ability to learn STEM; the opportunities of these early years trigger an appreciation of STEM and its value for everyday life (Campbell, Speldewinde, Howitt \& MacDonald, 2018).

Research by Tippett and Milford (2017) on educators, students and parents provides a glimpse of STEM education in certain pre-K settings. They reached four conclusions: (a) educators believe that STEM is a valuable component of the pre-K class; (b) students are actively involved in STEM activities; (c) parents respond positively to their children's STEM education; and (d) STEM can be an appropriate component of early childhood education. In addition, teachers who are influenced by STEM's integrated professional development and implementation of STEAM units result in children being positively affected by their teachers' professional learning and high confidence in teaching STEMrelated activities. An early childhood teacher's beliefs about what and how children should learn can critically influence children's acquisition of various knowledge and skills that emerge during the pre-school years (Kermani \& Aldemir, 2018)

The results of a study by (Linder, Emerson, Heffron, Shevlin \& Vest, 2016) show that the STEM curriculum offers many opportunities for students to be active and involved, and to take initiatives in their own learning. Based on observational notes taken by the researchers, a significant relationship can be seen between teacher content, pedagogical knowledge and children's learning. The higher the teacher's competence in pedagogical and STEM content knowledge, the greater the level of student engagement and conversation around STEM units and activities. These observations/findings are well supported by previous work, which shows a direct relationship between teacher learning approaches and student achievement, showing that students are more likely to learn from teachers with higher levels of instructional competence. 


\section{CONCLUSION}

Based on this review, it can be concluded that education in the 21 st century, which has entered a disruptive 4.0 digital era, must continue to innovate. Early childhood education, as one of the knowledge institutions, must also be prepared to answer the challenges of this era. This type of education needs to make changes to both curriculum and learning methods. STEAM learning is considered to integrate the skills needed by children. STEM encourages children to build knowledge about the world around them by observing, investigating and asking questions. The addition of 'Arts' (leading to the STEAM acronym), will give children the opportunity to describe the STEM concept in creative and imaginative ways. This review finds a definition for ' $A$ ' or 'Arts' in STEAM showing that the making of art and the creative process is overshadowed by the emphasis on the final result or product. For example, a study by Perignat and Katz-Buonincontro (2019) explains that students use various techniques to solve problems and demonstrate learning, and this includes attention to the humanities (the ' $A$ ' in STEAM) because they created media art and short videos written to present their solution. The impact of this learning is that STEAM makes children more active and able to take initiatives with their own knowledge, and teachers who are influenced by the integrated professional development of STEM prompt children to be positively influenced by their teacher's professional learning. Another finding from this review is that experience of STEAM can increase selfconfidence in children.

\section{REFERENCE}

Alam, I. \& Perry, C. (2002). A customer-oriented new service development process. Journal of Services Marketing. https://doi.org/10.1108/08876040210443391

Aldemir, J. \& Kermani, H. (2017). Integrated STEM curriculum: improving educational outcomes for Head Start children. Early Child Development and Care, 187(11), 1694-1706. https://doi.org/10.1080/03004430.2016.1185102

Andersson, K. \& Gullberg, A. (2014). What is science in preschool and what do teachers have to know to empower children? Cultural Studies of Science Education. https://doi.org/10.1007/s11422-012-9439-6

Ata Aktürk, A. Demircan, H. özlen, Şenyurt, E., \& Çetin, M. (2017). Turkish early childhood education curriculum from the perspective of STEM education: A document analysis. Journal of Turkish Science Education, 14(4), 16-34. https://doi.org/10.12973/tused.10210a

Avendano, L. Renteria, J., Kwon, S., \& Hamdan, K. (2019). Bringing equity to underserved communities through STEM education: implications for leadership development. Journal of Educational Administration and History, 51(1), 66-82. https://doi.org/10.1080/00220620.2018.1532397

Britto, P. R., Lye, S. J., Proulx, K., Yousafzai, A. K., Matthews, S. G., Vaivada, T.,Bhutta, Z. A. (2017). Nurturing care: promoting early childhood development. The Lancet. https://doi.org/10.1016/S0140-6736(16)31390-3 
Brophy, S., Klein, S., Portsmore, M. \& Rogers, C. (2008). Advancing engineering education in P-12 classrooms. Journal of Engineering Education. https://doi.org/10.1002/j.2168-9830.2008.tb00985.x

Buchmann, M. \& Schwille, J. (1983). Education: The Overcoming of Experience. American Journal of Education. https://doi.org/10.1086/443721

Campbell, C., Speldewinde, C., Howitt, C. \& MacDonald, A. (2018). STEM Practice in the Early Years. Creative Education, 09(01), 11-25. https://doi.org/10.4236/ce.2018.91002

Casey, T., Robertson, J., Abel, J., Cairns, M., Caldwell, L., Campbell, K., ... Robertson, T. (2016). Loose Parts Play. 72.

Davis, M. (2010). STEM Comes to Preschool. European Early Childhood Education Research Journal.

Dejonckheere, P. J. N., De Wit, N., Van de Keere, K. \& Vervaet, S. (2016). Exploring the classroom: Teaching science in early childhood. International Electronic Journal of Elementary Education, 8(4), 537-558. https://doi.org/10.12973/eu-jer.5.3.149

Doyle, M. (2017). Elements of Art. STEAM. https://doi.org/10.5642/steam.20170301.17

Draper, C. L. \& Wood, S. (2017). From Stumble to STEM: One School's Journey to Explore STEM with its Youngest Students. Exchange (19460406), 39(233), 61-65. Retrieved from $\mathrm{http}: / / 0-$ search.ebscohost.com.edlis.ied.edu.hk/login.aspx?direct=true \&db=ehh\&AN $=120822040 \&$ site $=$ eds-live \& scope $=$ site \& groupid $=$ Test

Gonzales, H. \& Kuenzi, J. (2012). Science, Technology, Engineering, and Mathematics (STEM) Education: A Primer. CRS Report for Congress Specialist in Education Policy., 34.

Han, C. \& Rosli, C. (2016). The Effect of Science Technology, Engineering and Mathematics (STEM) Project Based Learning (PBL) on students Achievement in four Mathematics topics. Journal of Science Education and Technology.

Henriksen, D. (2017). Creating STEAM with Design Thinking: Beyond STEM and Arts Integration. STEAM. https://doi.org/10.5642/steam.20170301.11

Herro, Q. \&. (2016). "Finding the Joy in the unknown": Implementation of STEAM Teaching Practices in Middle School Science and Math Classrooms. Journal of Science Education and Technology.

Jackman, H. L. (2009). Early Education Curriculum A Child's Connection to the World Fourth Edition. USA: WADSWORTH CENGAGE Learning.

Kermani, H. \& Aldemir, J. (2018). EXPLORING THE IMPACT OF A STEM INTEGRATION TEACHER PROFESSIONAL DEVELOPMENT PROGRAM ON EARLY CHILDHOOD TEACHER'S PEDAGOGICAL. (Celda). USA: Delmar Cengage Learning.

Krogh, S.L. \& Slentz, K. L. (2008). The Early Childhood Curriculum. New Jersey: Lawrence Erlbaum Associates, Inc.

Land, M. H. (2013). Full STEAM ahead: The benefits of integrating the arts into STEM. Procedia Computer Science, 20, 547-552. https://doi.org/10.1016/j.procs.2013.09.317 
Linder, S. M., Emerson, A. M., Heffron, B., Shevlin, E. \& Vest, A. (2016). STEM use in early childhood education: Viewpoints from the field. YC Young Children, 71(3), 87-91.

Madden, M. E., Baxter, M., Beauchamp, H., Bouchard, K., Habermas, D., Huff, M., ... Plague, G. (2013). Rethinking STEM education: An interdisciplinary STEAM curriculum. Procedia Computer Science. https://doi.org/10.1016/j.procs.2013.09.316

Maeda, J. (2013). STEM + Art $=$ STEAM. STEAM. https://doi.org/10.5642/steam.201301.34

Martín-Páez, T., Aguilera, D., Perales-Palacios, F. J. \& Vílchez-González, J. M. (2019). What are we talking about when we talk about STEM education? $A$ review of literature. Science Education, 103(4), 799-822. https://doi.org/10.1002/sce.21522

McClure, E. R., Guernsey, L., Clements, D. H., Bales, S. N., Nichols, J., KendallTaylor, N. \& Levine, M. H. (2017). STEM starts early: Grounding science, technology, engineering, and math education in early childhood. Retrieved from http://joanganzcooneycenter.org/publication/stem-starts-early/

Palou, E., Husted, S., Chávez-Torrejón, G., Ramírez Apud, Z., Gazca, L., Gutiérrez Cuba, V. J., ... López-Malo, A. (2015). Emerging Technologies for STEAM Education: Full STEAM Ahead. In Educational Communications and Technology: Issues and Innovations. https://doi.org/10.1007/978-3-319-02573-5_12

Perignat, E. \& Katz-Buonincontro, J. (2019). STEAM in practice and research: An integrative literature review. Thinking Skills and Creativity. https://doi.org/10.1016/j.tsc.2018.10.002

Purakom, A. \& Soykeree, T. (n.d.). STEM EDUCATION: INNOVATION EDUCATION FOR YOUNG GENERATION IN ASEAN. 9-12.

Radziwill, N., Benton, M. \& Moellers, C. (2015). From STEM to STEAM: Reframing What it Means to Learn. STEAM.

https://doi.org/10.5642/steam.20150201.3

Siantajani, Y. (2018). Playing with loose parts. Modul (tidak diterbitkan).

Soares, L. D. \& Petroski, E. L. (2003). Prevalência, fatores etiológicos e tratamento da obesidade infantil. Revista Brasileira de Cineantropometria e Desempenho Humano.

Taylor, C. P. (2016). Why is a STEAM Curriculum Perspective Crucial to the 21st Century? 14th Annual Conference of the Australian Council for Educational Research.

Tippett, C. D. \& Milford, T. M. (2017). Findings from a Pre-kindergarten Classroom: Making the Case for STEM in Early Childhood Education. International Journal of Science and Mathematics Education, 15, 67-86. https://doi.org/https://doi.org/10.1007/s10763-017-9812-8.

Yakman, G. (2018). Exploring the Exemplary STEAM Education in the U.S. as a Practical Educational Framework for Korea. (August). https://doi.org/10.14697/jkase.2012.32.6.1072

Yakman, G., \& Lee, H. (2012). Exploring the Exemplary STEAM Education in the U.S. as a Practical Educational Framework for Korea. Journal of The Korean Association For Science Education. 
https://doi.org/10.14697/jkase.2012.32.6.1072

Zhang, X., He, M., \& Zhang, Y. (2012). A review of research on the Kalina cycle. Renewable and Sustainable Energy Reviews, 16(7), 5309-5318. https://doi.org/10.1016/j.rser.2012.05.040 